\title{
Bank Holding Company Performance Studies and the Public Interest: Normative Uses for Positive Analysis?
}

\author{
DONALD M. BROWN
}

U NDER the Bank Holding Company Act of 1956 , the Board of Governors of the Federal Reserve System must consider the convenience and needs of the community when ruling on applications by bank holding companies to acquire bank subsidiaries. In each case, the Board must decide, first, whether the benefits ascribed by the applicant would be realized and second, whether the proposed acquisition wolld further the public interest.

In its past decisions, the Board has focused on some specific potential effects of holding company acquisitions in assessing whether the acquisition would further the convenience and needs of the community. A number of these appear to be related to standard financial ratios computed from the financial statements of banks. The impact of bank holding companies on these financial ratios has been investigated and widely reported in a host of batnk performance studies. Thus, although there is no evidence that the Board has used such studies in reaching its decisions, bank performance studies could provide useful information about holding company acquisitions.

The primary purpose of this article is to determine whether performance studies actually are capable of identifying performance differences among banks and, hence, whether they are relevant to policy decisions about bank holding company acguisitions. The first section briefly reviews the convenience and needs test as it relates to bank acquisitions and its implementation by the Board of Governors. The second section summarizes the results of previous performance studies. The third section investigates the conceptual difficulties with interpreting financial ratios as measures of bank performance. The final section draws conclusions about the implications of performance studies for both bank performance and public policy toward bank holding companies.

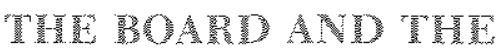 CONVWEHNCE AND NEEDS TEST}

Bank holding companies must apply to the Federal Reserve Board for permission to acquire a bank. ${ }^{1}$ In analyzing the application, the Board must consider the effect on the convenience and needs of the community and must weigh this effect against anticompetitive effects stemming from an acquisition. According to the present judicial interpretation of the Bank Holding Company Act, the Board cannot apply competitive standards stricter than those in the anti-trust laws (see box).

The Federal Reserve Board's treatment of convenience and needs in bank holding company applications has been investigated through examination of published Board orders relating to its various decisions. ${ }^{2}$

\footnotetext{
${ }^{\mathrm{E}}$ Bank Holding Company Act of 1956, as anended, 12 U.S.C. 1841 et sea.

Jules Backnam, The Bank Holding Company Act, Bulletin No. 24-25 (New York University, C.J. Devine Institute of Finance, Aprit-Ime 1963), and Michael A. Jessee and Steven A. Seelig "An Analysis of the Public Benefits Test of the Bark Holding Company tet "Federal heserve Bank of New York Monthly Reciew June 1974), pp. 151-62. These articles were reviewed by Anthony $W$. Cymak, Convenicnee and Needs and Publie Benefts in the Bank Holking Company Movement," in The Bank Holding Company Mocoment to 1978: A Compendium (Boxd of Govemors of the Federal Reserve System, 1978 ), pp. 263-89. Jessee and Seelig later updated their study through ane 1976; their findings, with respect to the Boirds treatment of convenfence and needs in bank acquisitions, essentialy were unchanged from their original study. See Michatel A. Jessee and Steven A. Seelig, Bank Holding Companies and the Pablic Interest (D. C. Heath and Company, 1977), chapter 5 .

The Jessee and Seelig study is more relevant because its sample period, January 1971 to mid-1974, postdates anendments to the Bank Holding Conpany Act. The early 1970 was a pertod of raph bank holding company expansion. During the $3 \frac{1}{2}$ years covered by the Jessee and Seelig study, the Board issued orders approving 434 holding compiny applications to acquire banks, while $4 t$ denial orders were issted including orders denying some nom-bank acquisitions). Comparatively, only $3 i$ orders were issued during Backman's simple period of $1956-62$.
} 


\section{Legal Provisions and Interpretation of the Bank Holding Company Act}

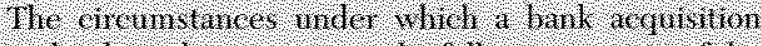

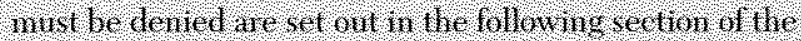

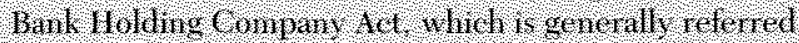

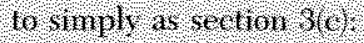

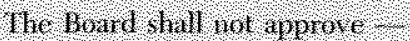

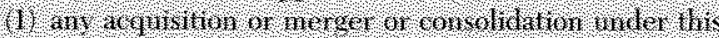

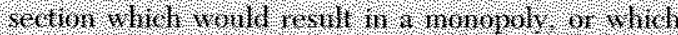

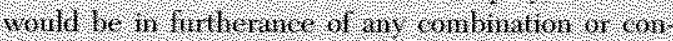

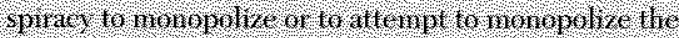

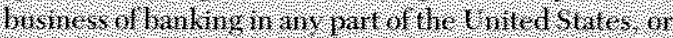

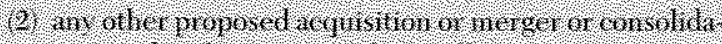

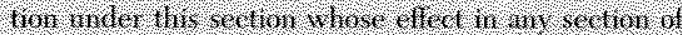

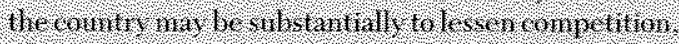

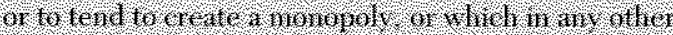

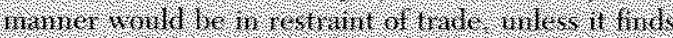

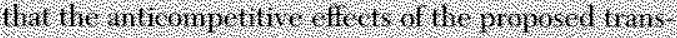

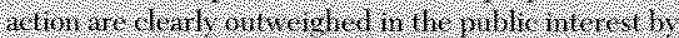

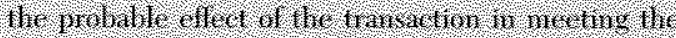

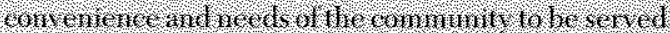

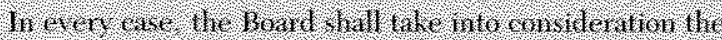

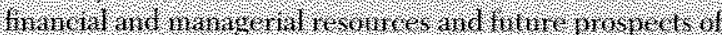

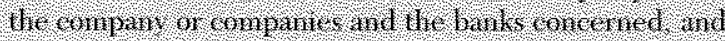

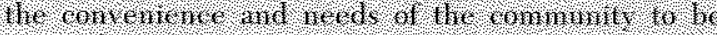
struta:

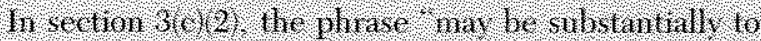

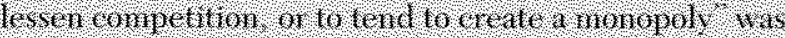

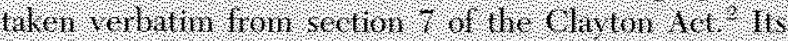

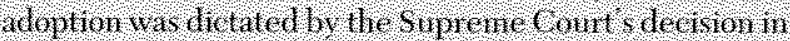

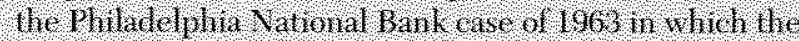

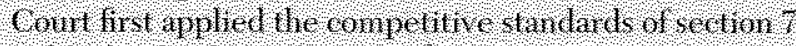
to block a bank conthination ?

$12,5,18420$

$150,5,0.18$.

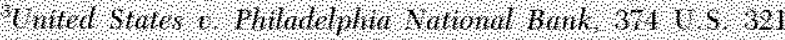
1863

In these published orders, the Board addresses the benefits clamed by the applicant; it also may cite factors it finds inimical to the convenience and needs of the community. "The benefits most often cited in orders approving bank acquisitions by holding companies are shown in exhibit $\mathrm{A}^{+}$

\footnotetext{
The orders are legat documents, written according to a formula and varying little in their worling. The effect of bank acquisitions on convenience and needs is described frequently as "consistent with appoval." The orders do ant include an analysis of the quantitative effect of prospective benefits; consequent at benefit in any application generally is not evident from the text of the order.

${ }^{1}$ Jessee and Seelig Bark Holding Companies, tahle 5-1, pp. 52-53. The sane table with only minor changes appears in Jessee and
}

The Claytor Aet does not nention a counter wiling role for conve nience and needs. In the Pliwhelphindecision. the coun as sefted thit a mer get the effee of which way be sulistantially to lessen compefition is not saved he: catse. on sone ultinite reckoning of soctal or economic debits and credits it nay be deemed benefichal ?t Whether the amerded Bank Holding Company tet has precedence over the anti-tmust laws is a legal question. It his been moot so far because the Board has never approved an acquisition when if found an anit thist violac lion.

The Boand mamtans liat he last seplence of section 3(6) suthunes actual or petential adver se competines effects that do not antomit to tolations of the intr-trist

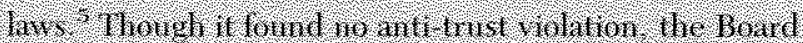
in 1979 dented on compritive gromid the auplication of Count National Baiconperation to actuire T. C. Bance share Company beranse enisiderations reliting of the

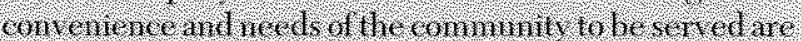
insufferent to untweigh the anticomperitive eflects that would resilf from consummation of this proposal the This

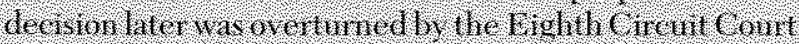
of Appeals? Thus the present judicial intentetation is that convenience and needs effects are distinct from ant?

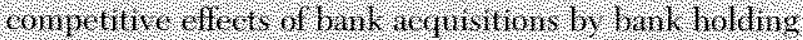
companies

16.6 $, 1,31$

712 C1 I 250152

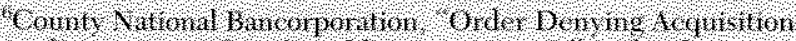

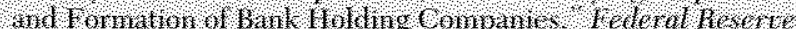

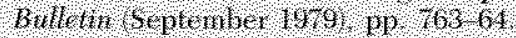

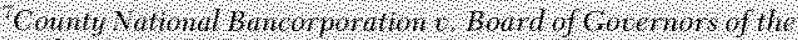

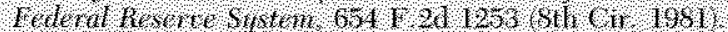

\section{What Comenenes? Whose Needs?}

The Board of Governors has a difficult task in implementing the convenience and needs test. A chief diffeulty is that the interests of all sectors of the commumity do not coincide. A policy of making only "riskfree" loans, for example, may benefit some depositors at the expense of prospective bonrowers and the bank's

Seelig, "Andysis of Public Benefts Test," table 1, p. 153. "The authors" use of six categories of benefits is misleading, as section 3 ic of the Bank Holding Company Act reentiates that benefits fit into three categories: finuncial or matagenial resonces, futze prospects or convenience and needs. 


\section{Exhibit A \\ Benefits Cited in Orders of Approval \\ Convenience and needs.

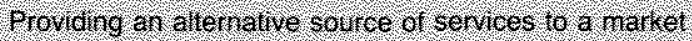 hereased lendig capacty to support strong econemic glowth in an area \\ hereased lencing ceraciv 16 stmulate growh hrecononicoly depressed areas \\ Expansion of spectalized credil services: \\ haceased competition. \\ Increased competiton through de novo entry \\ Redwction of ales charged on toans or oner services \\ Strenghering he conpetive postion of a small him through Gflation with a larger bank holding company \\ Increasing competition by chang ho a limited serve e nstitution into a fillserves tin \\ Changing a conser vative tim hto a more aggresshe compel: tor \\ improved efficiency: \\ Econonines or scale \\ Complenentary skils: \\ Improved financial resources: \\ Acquring a linencally weak tirn \\ Inorowing the detw to equity atio of the acquired tim

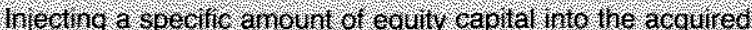 $1 \mathrm{~min}$ \\ Providing access to the greater inancal resources" of the lolding company \\ lifecting a spectic amoun of eouty capial hto oxisting bank subsidary \\ Inproved nanagetial resources. \\ Allevating management succession ploblens. \\ Providing rnanagenent depth \\ Access to managerial resources of holding company \\ Other benetits: \\ Lowering nanadenent tees for subsidiay banks}

stockholders. ${ }^{5}$ A relevant social welfare function would be required to relate the anticipated effects of bank holding company acquisitions theoretically to "the public interest." Economists have not produced such a

\footnotetext{
5ome prospective borrowers wonld be denied credit and stockholders would eam a lower retum on their investments. Depos* itors who are restricted to below-market interest rates (for example, a zero rate on non-persomal demand cleposits) probably could not gain, but might lose, if the bank made "risky" loans.

The interest of the bank's stockholders is of only secondary concern, because the Boards legislative mandate is to safeglard the convenience and needs of the community. Jessee and Seelig cite statements to this effect by menbers of the Board. See Jessee and Seelig, "Analysis of Public Benefits Test," p. 161.
}

function; consequently, the benefits cited by the Board, at best, are ad hoc approximations to the public interest. This is generally the best that can be done when normative assessments are required.

A separate issue that the Board must face is whether the effects that it has associated with convenience and needs will actually result if the acquisition is approved. For example, will an acquisition actually convert a staid bank into a more aggressive lender? Empirical investigations of this issue are available in a host of bank performance studies that have examined the effects of ownership on bank operating characteristics. Thus, in this instance, positive studies of bank operating characteristics might provide some useful background for the normative evaluations required of the Board.

\section{MESULTS OF PERTORMANCE STUDIES}

Performance studies have used different samples and empirical approaches. Not surprisingly, they often have attributed different effects to bank holding company ownership; they are remarkably consistent, however, in several important ways.

First, the studies have found virtually no difference in financial ratios between independent and bank holding company banks, prior to the acquisition of the latter by holding companies.

Second, holding company banks generally hold a higher proportion of their assets in loans and the obligations of states and municipalities, and a smaller proportion in cash and U.S, govermment securities, than comparable independent banks.

Third, bank holding companies generally have not had a sizable effect on the performance measures of their subsidiary banks. Holding company ownership typically has had a statistically significant ffect on only a small proportion of the financial ratios included in the various performance studies. It has not been near the top of the list of factors that influence measures of bank performance. ${ }^{6}$ The single exception is the study re-

\footnotetext{
GManne and Jackson each computed beta coefficients, which are intended to measure the relative importance of the independent variables in a multiple regression. They both estimated several regession equations, so their results cannot be summarized conve. niently. In most of their regressions, bank holding company ownership was of midding or lesser importance. See Lucile S. Mayne, "A Comparative Study of Bank Holding Company Affliates and Independent Banks, 1969-1972,"Journal of Finance (March 1977), pp. 147-58; and William Jackson, "Multibank Holdnex Companies and Bank Belavior" Working Paper $75-1$, Federal Reseve Bank of Richmond, July 1975).
} 
porting that holding company banks are more highly leveraged than independent banks. '

In other respects, the findings have been less consistent. There is conflicting evidence on the effects of holding company ownership on (1) service charges on demand deposits and interest rates on time and savings deposits, (2) operating expenses, and (3) financial leverage (the ratio of total assets or debt to capital). Table 1 summarizes the results of performance studies.

\section{A

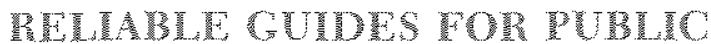 POLICY?}

Bank performance is worth investigating, regardless of its implications for public policy toward bank holding company acquisitions. If the methodology is valid, bank performance studies can help economists understand how market characteristics affect bank operating results and why bank holding companies account for an increasing share of banking activity. But these studies also may indicate the likelihood that some of the benefits identified in previous Board orders will result from acquisitions of banks by bank holding companies.

Consider again exhibit $A$, the benefits cited in previous Board orders approving bank holding company acquisitions. Some of these benefits could be measured by financial ratios: The level of a specialized credit service could be represented by the ratio of a particular type of loan to the loan portfolio. Competition or the interest rate on loans could be represented by the ratio of interest revenue to the loan portfolio. Aggressiveness could be measured by the ratio of total loans to total assets. Economies of scale could be measured by the ratio of operating costs to total assets. The debt-to-equity ratio could be computed from a bank's financial reports. Other benefits are unrelated to financial ratios; management "depth" or problems of succession, for example, cannot be measured by any ratio.

The same financial ratios that could be used to measure certain prospective benefits of bank holding company acquisitions also appear in performance studies as measures of bank performance (see table 1).

Bank performance studies share a common methodology. They compare independent banks and bank

\footnotetext{
Mingo found thizt the difference increased with the level of market concentration. In the most highly concentrated banking ratarket in his sample, the ratio of capital to total assets was 38 percent lower in bolding conmany banks, other factors hek constant. The lower ratio is equivalent to higher leverage. See John J Mingo, "Managerial Motives, Market Structures and the Performance of Molding Company Banks," Economic Inquiry (September 1976), pp. $411-24$.
}

holding company subsidiaries on the basis of various financial ratios, computed from the consolidated reports of income and condition that all insured banks periodically file with their regulators. These reports have standard formats that vary only slightly for large banks and banks engaged in certain foreign enterprises." The same financial ratios, therefore, can be compared for all insured banks. The performance studies hypothesize that "good" or "bad" performance depends on the values of these financial ratios. Neither the relationship between performance and the financial ratios, nor the predicted effects of bank holding companies on the ratios, is derived theoretically. Like the measures of the public interest discussed previously, these ratios represent ad hoc measures of performance.

Are these ratios reliable guides to either bank performance or the public interest? It seems not. ${ }^{9}$ First, the empirical approaches employed in performance studies have various shortcomings. Second, these ratios are distorted by differences in accounting method, organizational structure and portfolio composition that cannot be captured by balance sheet and income statement data; moreover, they are not strictly comparable across independent banks and holding company banks.

\section{Weaknesses of Empirical Appronches}

Early performance studies used t-tests of differences in the means to evaluate the effects of holding com-

\footnotetext{
The reports consolidate the funancial results of a banks main ofice, subsidiaries and branches (if any).

${ }^{4}$ Bank performance studies generally did not draw policy implications from their mindigs. Although early studies made explicit reference to the statutory convenience and needs test, their condusions generally were limited to discussions of bank performance. Liter studies did not refer to the convenience mat needs test. Mayne went so far as to say that her results "do not relate to increased services or convenience. . "See Mayne. "Comparative Study," p. 157. If she was referring to the Federal Reserve Board's intempretation of the public interest, then she was too cimcimspect. On the other hand, Jackson averred that holding company acquisitions of "well-managed" banks promise "few pubtic benefts." See Jackson, "Multibank Holding Companies," p. 26.

Despite their unwillingness to make policy recommendations, the authors of performance stalles apparently have an implict standard for deciding whether bank holding companies are beneficial. For example, Rose and Scott described a higher ratio of other expenses to total assets among holding company banks as "alarming" and a lower ratio of farm real estate loans to total assets among holding company basks as at "deficiency." See Peter S. Rose and William L. Scott, "The Pefformance of Banks Acquired by Holding Companies," Retiete of Business and Economic Research (Spring 1979), pp. 29 and 31 . All the performance studies refer to "bank performance." The term implies an objective or subjective stan. dard for distingushing superior from inferior performance.
} 
Table 1

\section{Empirical Results of Performance Studies}

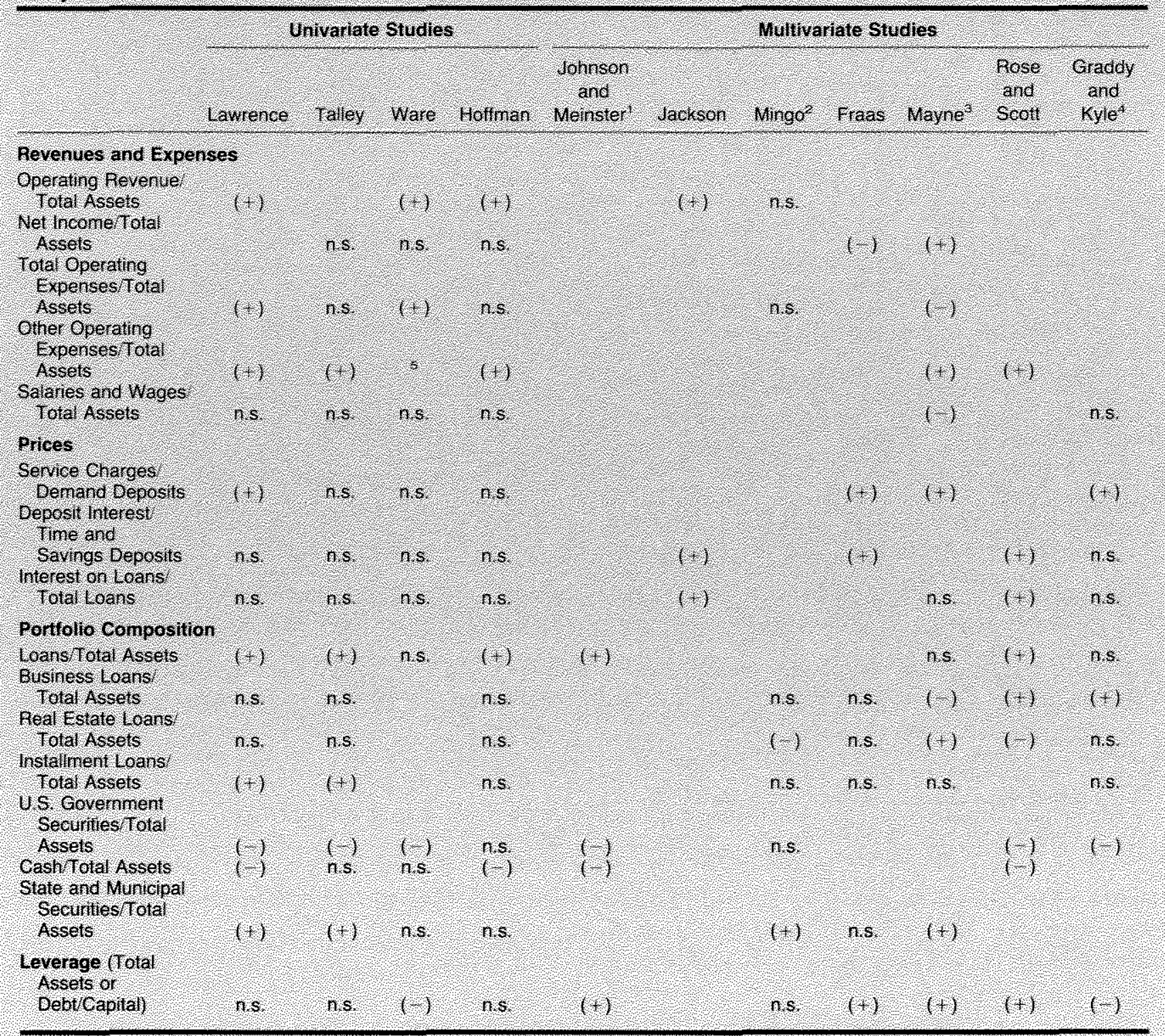

ns. Not stakisticaly significant at the conticence level selected by the author(s).

(1) Indicates that he tinancial ratio was higher lor holding company banks, ceteris paribus.

1 I lndicates that the financial ratio was lower tor holding company banks, celeris paribus

The tour financial ratios ndicated as signiticant were the independent variables in a nuiliple-discriminari analysis that compared independent and holding company banks tour years after the latter were acqured by holding conpanies.

The reported lesults refer to the coeficient of the holding conpany dummy variable, in adoition, an interaction variable between concentration and the dunny variable was positive and statistically signitcant in the equation for real estate oansitotal as sets and negative lor bustness loans/total assets and capital total assets.

3 Mayne estimated equations tor each of the four years 1969,72 The lesults are reported here as significant if the dummy variable she used entered an equation signiticanty in at least wo of the four years.

${ }^{T}$ The reported results refer to the coeficient of the holding company dummy variable, In adoliton, six different hiteraction variables involving the dummy variable were statisticaly signiticant in al least one of the authers 13 equations In hree equations, two of the interaction variables were statisticaly significant and in five equations, one of the interaction variables was stalistically significant

5 h the t - tests of differences in the means holding company banks were found to have had a higher ratio of other operating expenses to lotal assets in the second year following acquisition by a holding company, but a lower ratio in the third year 
panies on the post-acquisition performance of subsidiary banks. ${ }^{10}$ In attempting to control for the influence of other factors on performance, these studies patred holding company banks with similarly-sized independent banks from the same market. These studies failed to adequately control for bank size and market characteristics, and high correlations among financial variables made univariate tests of statistical significance uninterpretable. ${ }^{11}$ The tmivariate studies also can be criticized for elminating from further study banks that could not be suitably paired.

Most recent performance studies have used multivariate statistical techniques, principally multipleregression analysis. ${ }^{12}$ Until recently, the multipleregression models were single-equation models, which were estimated using ordinary least squares regression analysis. These models compared performance at a point in time, rather than over a postacquisition period. The effect of holding companies on bank performance was estimated by including a dummy variable representing holding company ownership. Some studies also included interaction variables. ${ }^{13}$

The multivariate studies have several weaknesses. First, most of them presumed that performance differ-

\footnotetext{
${ }^{16}$ Robert J. Lawrence, The Performance of Bank Holding Compenies (Board of Governors of the Fedenal Reserve System, 1967); Samuel H. Talsey, The Effect of Holding Company Acquisitions on Bank Performance. Staff Fonomic Studies 69 (Board of Governors of the Federal Reserve Systen, 1971); Robert $\vec{F}$. Ware, "Performance of Banks Acquired by Multi-Bank Holding Companies in Oho," Federal Reserve Bank of Cleveland Economic: Reciew March-April 1973), pp. 19-28; and Stuart G. Hoffuan, "The Impact of Holding Company Affilitation on Bank Performance: A Citse Study of Two Florida Multibank Holding Conpanies" (Working Paper Series, Federal Reserve Bank of Atlanta, Januay 1976 ).
}

"Rodney D. Johnson and David R. Mensinster, "An Analysis of Bank Holding Company Acquisitions: Some Methodological Issues," Journal of Bank Research (Spring 1973), pp. 58-61.

${ }^{12}$ Rodney D. Johnson and David R. Meinster, "The Performance of Bank Holding Company Acguisitions: A Multivariate Analysis," Joturnal of Business (April 1975), pp. 204-12, Jackson, "Maltibank Holding Companies;" Arthur G. Fradas, The Performance of Individual Bank Holding Companies, Staff Economic Studies 84 (Board of Covemors of the Federal Reserve Svstem, 1974); Mingo, "Managerial Motives, Market Structures and Perfor" mance," pp. 411-24; Mavne, "Comparative Study," pp. 147-58; Rose and Scott, "Performance of Banks," pp. 18-37; and Duine B. Graddy and Reuben Kyle, III, "Affilated Bank Performance and the Simultaneity of Financial Decision-Making, Journal of Finance (September 1980\}, pp. 951-5i. Johnson and Veinster used multiple-discriminant analysis: the others used multipleregression andysis.

1/3hese were the studies by Mingo, and Gaddy and Kyle. See Ibid. The interaction variables were products of the dummy variable and other independent variables. They tested the hypothesis that an independent variable's effect on bank performance depeuded on the bank's form of ownership. ences at a point in time were due to changes in performance after the acquisition. Second, some studies continued to pair independent and holding company banks. ${ }^{14}$ Third, high multicollinearity involving interaction variables may have biased the coefficient estimates. Finally, single-equation models ignore interdependence among bank decisions, ${ }^{15}$

Graddy and Kyle attempted to account for interdependencies among financial ratios by estimating an ad hoc system of 13 equations. Although it was an improvement over earlier models, their model did not capture the hypothesized complexity of the interdependence among bank decisions; furthermore, their interpretation of certain financial ratios was questionable. ${ }^{16}$

\section{Distorions in Punacial Patios}

Specific distortions in the financial ratios can be traced to the nature of the banking firm and the bank holding company, and to the effect of regulation on bank prices. Banks sell many different products and acquire many different deposit liabilities. Reventes and expenses depend on portfolio composition, and prices depend on the size, type and risk of the assets and liabilities in the portfolio. Bank holding companies are vertically and horizontally in tegrated corporations. This form of organization potentially affords real advantages, but also creates accounting differences between independent and subsidiary banks. Deposit ceilings place a statutory limit on the price of certain kinds of deposits, causing banks to engage in non-price competition for loanable funds.

Problems avin watios as Measures of price - Performance studies represent the prices that banks

\footnotetext{
Whese were the studies by Johnson and Menster, and Vayne. See Ibid. The fomer study actually used a sample of banks from Lawrence's original performance study.

${ }^{15}$ Duane B. Graddy and heuben Kyle, III, "The Sintutaneity of Bank Decision-Making Market Structure, and Bank Performance," Jow rnal of Finance (Varch 1979), wp. 1-18. "This interdependence canses the high correlations among financial ratios roted earlier by Johnson and Meinster. The use of single equation regression models under these circumstances introduces simultaneous equation bias into the ordinary least squares estimates of the regression coefficients. Note that this criticism does not pertain to the Johnson and Meinster stukly, in which financial ratios entered only as independent variables in a nultiple-discriminant analysis.

${ }^{16}$ The anthors choice of financial ratios to represent input and output decisions led them to interpret certain ratios as quantities. For example, the ratios of total loans to total assets, and salaries and wages to total assets, were interpreted as cuartities of output and input, respectively. The authors interpretation of the ratio of total capital to total risk assets as the bank's lending limit is donbtiul. See Ibid., pp. $7-8$.
} 
charge for their products and pay for deposits as ratios of income statement items to balance sheet items. For example, the price paid for deposits has been measured by the ratio of interest paid on deposits to total time and savings deposits, and the price of loans by the ratio of interest received on loans to the loan portfolio. There are four reasons that these financial ratios are inadequate proxies for such prices.

First, the ratios do not account for a bank's portfolio composition. ${ }^{17}$ The sizes and types of a bank's loans or deposits affect its operating costs and, hence, the prices the bank both pays and charges. These effects are not captured by the ratios of income statement to balance sheet items. Such ratios are actually weighted averages of many different prices; they measure average revenues and average expenses rather than prices.

Second, the ratios include risk premiums. Banks can be expected to charge higher rates of interest on loans with greater perceived default risk. Banks that choose to make riskier loans will tend to have higher average revenue from loans (and also more bad debts), athough they may charge the same rate as other banks for loans of comparable default risk. Interest rate risk increases with the maturity of loans. Banks that choose to make longer-term loans also will tend to have higher average revenue from loans.

Third, the ratios fail to account for the effects of price ceilings on some deposits. When the legal rate of interest on deposits is fixed below the market rate, banks have an incentive to incur non-interest expenses to attract deposits. These additional costs are not counted as interest expense on a bank s income statement. Consequently, the average expense ratio understates the true cost of deposits. This understatement is probably greater for some banks than for others, depending on the demand and supply conditions for deposits in different banking markets.

Fourth, the ratios fail to account for interdependencies among certain prices. Some banking services are purchased in a package, for example, a borrower's agreement to maintain a compensating balance with the lending bank in return for a lower nominal rate of

\footnotetext{
Traddy and Kyle did aceount for certain aspects of portfolio composition. Their equation for the average interest rate on loans included as argments the ratios of business, real estate, and installment loans to total assets. Their equation for the average deposit rate included as arguments the ratios of demand deposits to total deposits and savings deposits to total time and savings deposits. See Ibid., p. 9. These specifications are an improvement over those of other performance studies; nevertheless, they fail to account for many aspects of portfolio composition, including size differences within any category of loans or deposits.
}

interest on a loan. The true interest rate depends on the size of the compensating balance; however, the ratio measuring average loan revenue depends only on nominal rates.

Different average revenue and expense ratios are not necessarily due to different prices for a standard product. Systematic differences in portfolio composition, risk or other business strategies between independent banks and holding company banks cause systematic differences in the average revenue and expense ratios. The ratios are ambiguous guides to the prices banks charge for products and pay for deposits.

Problons wh Ratios as Measures of Effichoy-In performance studies, the term "efficiency" is used to describe the relationship between bank costs and some measure of output, generally total assets but occasionally total revenue. The relationship between total costs and output is measured by the ratio of operating expenses to total assets or total revenue; the relationship between two particular elements of total cost is measured by the ratios of salaries and wages expense to total assets and other operating expenses to total assets. Smaller values of these ratios are interpreted as evidence of lower cost (i.e., more efficient) production. This interpretation is invalid.

Banks are multiproduct firms that obtain funds from a variety of sources. Some banking products and some sources of funds are more costly than others: therefore, the operating expense ratios depend on the composition of a bank's portfolio. Presumably, more costly portfolios yield higher revenues, so the ratio of operating revenue to total assets depends as well on portfolio composition. Because operating revenue also depends on the control the bank exercises over price, no ratio incorporating operating revenue is an adequate proxy for a bank's cost of production.

Bank holding companies are vertically integrated organizations; the parent company provides a variety of services to its subsidiary banks. In some cases, these services have been centralized in the holding company as an economy measure. In other cases, the salaries of some bank employees are assigned arbitrarily to the parent company instead of the subsidiary. In either case, the salaries of some employees who provide services to a subsidiary bank are carried on the books of the holding company instead of the bank itself. This introduces a systematic downward bias into the reported salaries and wages expense of holding company banks and, thus, a downward bias into the salaries and wages expense ratio of holding company banks. 
Some bank activities are more labor-intensive than others. Consequently, the salaries and wages expense ratio may vary systematically between holding company banks and independent banks due to differences in portfolio composition. This source of distortion may reinforce or offset the downward bias discussed in the preceling paragraph.

Bank holding companies asually charge their subsidiaries for services provided by the parent company. These charges, which are internal accounting transfers, are referred to as management fees. As the "other operating expense" category on a bank's income statement includes management fees, this expense is biased upward if holding companies charge their subsidiary banks for services provided.

Problems with Levenge as a Measure of Caminl Adequats or Risk - Leverage is the ratio of debt to capital. A bank's leverage may reflect the attitudes of owners or managers toward risk; it may be related to other factors as well. Performance studies have advanced one reason that holding company banks should be less highly leveraged and another that they should be more highly leveraged, irrespective of attitudes toward risk.

Some performance studies have argued that bank holding companies have greater access to capital markets than independent banks. As this advantage should translate into a lower cost of capital, banks owned by holding companies should hold more capital in relation to debt than independent banks. On the other hand, holding companies also are better able than independent banks to diversify geographicaly. ${ }^{18}$ Other performance studies have argued that geographically diversified holding companies reduce their risk by lessening their dependence on any single geographic area. With this advantage, they should require less capital for any given level of debt. Both arguments have been used to rationalize empirical results. Because the arguments do not unambiguously predict the effect of bank holding companies on the ratio of debt to capital, leverage measures neither capital adequacy nor risk.

\footnotetext{
Bank holding compantes can own non-bank subsidiaries in any state, whereas banks are limited $n y$ state branching restrictions. Banks cannot locate offices in states other than their home states, and in some states are limited to conducting all or most of their business from a single office. In states that restrict branching, multibank holding companies can circumvent legal restrictions on the geographical extent of a bank's operation by acquiring or chartering banks in different areas of the state. Thus, to some extent they are substitutes for branch banks.
}

Certain accounting conventions obscure any comparison of the capital of holding company banks and independent banks. Holding companies can borrow funds to augment the reported capital of their subsidiary banks. (This practice is known as double leveraging.) For accounting purposes, the funds are capital to the bank and debt to the holding company; therefore, the effect of the borrowing is to increase the leverage of the parent company and decrease the leverage of the subsidiary bank.

Does double leveraging improve the capital position of the bank? To put the question differently, is a bank that borrows through its parent holding company actually exposed to less risk than an independent bank that incurs the same debt itself? The answer depends ultimately on whether a subsidiary bank is insulated from the financial problems of its parent company. On one hand, the bank is a separate legal entity; the holding company is prohibited legally from draining the bank of its assets or capital. On the other hand, the operating policies of the bank are dictated by the parent company; if faced with insolveney, the holding company is likely to operate the bank in a risky manner in an attempt to meet the interest payments on its debt. It seems that the practice of double leveraging obscures the distinction between debt and capital, causing an overstatement of the capital positions of subsidiary banks and an understatement of risk.

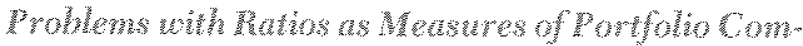
posifion - Several portfolio ratios are used in performance studies. They measure the proportions of total assets held as loans, cash, U.S. govermment securities and so forth, and the proportions of the loan portfolio devoted to different kinds of loans, such as business, real estate and installment loans. Differences in portfolio mix are partly responsible for the biases in other financial ratios.

The portfolio ratios are less subject to potential distortion than other financial ratios. Nevertheless, certain portfolio ratios may be biased due to the division of a bank holding company into bank and non-bank subsidiaries. This division creates reporting differences between holding company and independent banks. For example, a mortgage loan by an independent bank would be reported on the bank's call report, but the same loan by a holding company's mortgage subsidiary would appear on the books of the non-bank subsidiary. Although non-bank subsidiaries account for a small proportion of total holding company activities, the legal and accounting divisions may distort particular portfolio ratios, such as the ratio of real estate loans to total loans. 
The portfolio ratios do not indicate unambiguotsly the extent of lending to the local community. A higher ratio of loans to total assets is not necessarily evidence of greater local lending, because some loans on the bank's books may represent loan participations or purchased paper.

\section{CONCWOSON}

The financial ratios used in bank performance studies are subject to substantial distortion when used to assess the impact of bank holding companies on bank performance. These distortions are attributable to the nature of the banking firm and the bank holding company organization, and to the effect of regulation on deposit interest rates. As a result, the performance studies generally have not provided reliable evidence about the effect of bank holding companies on either bank performance or the factors that the Board of Governors has identified as prospective benefits of holding company acquisitions.

Previous investigations have found that the Board of Governors has not given much weight to convenience and needs. The finding that orders approving bank holding company acquisitions "seldom dwelt" on the benefits of the case when an acquisition had an unim- portant competitive effect, and the slight weight given prospective benefits in orders of denial seem to stopport this conclusion. ${ }^{19}$ This is consistent with the results of past performance studies, which usually have attributed only small effects to bolding companies, and often have contradicted each other at that.

There is no evidence that the Board has relied on either financial ratios or the results of performance studies in reaching its decisions. The assessment made in this article indicates that it should use neither. Although the shortcomings of previous empirical approaches eventually may be overcome, the problems with using financial ratios to measure either performance or the public interest appear intractable.

Performance studies are not without potential value, however. If properly designed, the studies can identify differences between the reported operating results of independent banks and holding company banks. These differences may suggest directions for research in to the incentives for bank holding company formation and growth. But they are not likely to provide useful evi. dence of the desirability of bank holding company acquisitions.

"19essee and Seelig, "Analysis of Public Benefits Test," pp. 161-62.

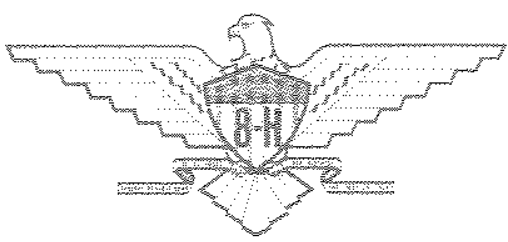

